\title{
Photosynthesis, Photosynthate Translocation and Metabolism in Cucumber Roots Held at Supraoptimal Temperature
}

\author{
Yong Chen Du and Shoji Tachibana \\ Faculty of Bioresources, Mie University, Tsu, Mie 514
}

\begin{abstract}
Summary
Cucumber plants (Cucumis sativus L. cv. Sharp I) with 3 leaves were grown in hydroponics at root temperatures of $25^{\circ}, 32^{\circ}, 35^{\circ}$ and $38^{\circ} \mathrm{C}$ for up to 9 days. The rates of photosynthesis and transpiration as well as leaf chlorophyll content was not affected by the root temperatures from $25^{\circ}$ to $35^{\circ} \mathrm{C}$. In plants grown at $38^{\circ} \mathrm{C}$ the rates of photosynthesis and transpiration were unaffected over the first 5 days, but a large decrease occurred in the two parameters as well as chlorophyll content after 9 days. When a shoot was pulse-fed with ${ }^{14} \mathrm{CO}_{2}$ after 6 days growth at $25^{\circ}$ or $38^{\circ} \mathrm{C}$ root temperatures, translocation of ${ }^{14} \mathrm{C}$-photosynthates to the roots during a 10 -h chase in darkness was faster at $38^{\circ} \mathrm{C}$ than it was at $25^{\circ} \mathrm{C}$. However, the amounts of the ${ }^{14} \mathrm{C}$ accumulated per unit dry weight of root tissue were not different between the two treatments, becuase of an increased carbon loss by respiration of the roots at $38^{\circ} \mathrm{C}$. At $38^{\circ} \mathrm{C}$, more ${ }^{14} \mathrm{C}$ was allocated to soluble $\mathrm{C}$ than to insoluble $\mathrm{C}$; the reverse was the case at $25^{\circ} \mathrm{C}$. Fractionation of soluble ${ }^{14} \mathrm{C}$ into sugars, organic acids, and amino acids revealed that in the roots at $38^{\circ} \mathrm{C}$, a very large proportion of ${ }^{14} \mathrm{C}$ was in the sugar fraction, particularly raffinose. This was in contrast to the $25^{\circ} \mathrm{C}$ roots in which the soluble ${ }^{14} \mathrm{C}$ was distributed evenly to the three fractions. Possible relationśhips of the changes in photosynthesis and photosynthate translocation and metabolism in the roots with root growth and functions under the high root temperature conditions are discussed.
\end{abstract}

\section{Introduction}

High ambient temperature is one of the major environmental factors that limit vegetable crop production, particularly in soilless culture in the hot seasons (Murata et al., 1975). Accumulating evidence indicates that the deleterious effects of high ambient temperature on whole plant performance are primarily mediated through root dysfunctions cuased by high temperature in the root-zone (Kuroyanagi and Paulsen, 1988; Chaisompongpan et al., 1989; Sasaki and Itagi, 1989), although high air temperature can directly impede the growth of aerial plant parts and the development of reproductive organs in particular (Sugiyama et al., 1966; Rudich et al., 1977; Reynolds and Ewing, 1989).

The deterioration of some physiological processes in the root, such as water and ion uptake (BassiriRad and Radin, 1992), respiration and car-

Received for publication 28 January 1994. bohydrate metabolism (Gur et al., 1972; Janes et al., 1988), and cytokinin synthesis (Itai et al., 1973) has been indicated to be involved in the dysfunction of the root at supraoptimal root temperatures.

Among the physiological processes that form the basis of root growth and functions, translocation of photosynthates to the root is of fundamental importance, because the root is completely dependent on the carbon assimilates supplied by leaves. However, the effect of high root temperature on this physiological process as well as metabolism of photosynthates in the root has not been well documented. At high root temperatures, translocation of photosynthates to roots was reduced in potato (Sattlemacher et al., 1990b), but was unaffected in Japanese holly (Ruter and Ingram, 1990). In tomato no clear relationship was observed between the accumulation of ${ }^{14} \mathrm{C}$-photosynthates in the root and root temperatures rang. ing from $22^{\circ}$ to $35^{\circ} \mathrm{C}$ (Hurewitz and Janes, 1983).

Our previous study (Du and Tachibana, 1994) 
showed that exposure of cucumber roots to supraoptimal temperatures resulted in a marked increase in root respiration rate and total soluble sugar content. These results indicate that the photosynthate translocation to the roots is not inhibited by high root temperatures in cucumber. Thus, we suggest that the disturbance of normal metabolism rather than the shortage of photo. synthates in the root may be primarily involved in the mediation of inhibitory effect of supraoptimal temperatures on the root growth and functions.

High temperature has been shown to block the incorporation of photosynthates to insoluble compounds in the sink organs (Dinar and Rudich, 1985; Ruter and Ingram, 1990) partly because of reduced hydrolysis of the imported sucrose (Dinar and Rudich, 1985). In our previous experiment with cucumber plants exposed to high root temperatures, we noted a significant increase in raffinose and stachyose among the soluble sugars. As cucumber is a stachyose translocator (Grooss and Pharr, 1982), its accumulation indicates the hindrance of high root temperature to the metabolism of raffinose and stachyose. However, the possiblity that translocation of photosynthates to the root exceeds their utilization can not be ruled out without further evidence. Thus, the objective of the present study was to clarify the effect of supraoptimal root temperatures on the photosynthesis, ${ }^{14} \mathrm{C}$ photosynthate translocation and metabolism in cucumber.

\section{Materials and Methods}

\section{Experiment 1. Effect of high root temperature on the leaf photosynthesis and transpiration}

The experiment was carried out in April in a greenhouse under natural light with mean air temperatures of $26^{\circ} \pm 3^{\circ} / 20^{\circ} \pm 3^{\circ} \mathrm{C}$ (day/night). Cucumber seedlings raised by gravel culture were transplanted to a half-strength Hoagland solution at the beginning of 3-leaf stage. After 4 days, the solutions (root) were kept to $25^{\circ}, 32^{\circ}, 35^{\circ}$ and $38^{\circ} \mathrm{C}$. Five and 9 days after the start of treatment (both sunny days), leaf photosynthesis and transpiration rates were measured from 10:30 to $12: 00$ using a portable photosynthesis and transpiration measurement system (SPB-H, Shima-dzu). The measurements were made on 3 or 4 successive leaves starting with the third leaf from stem apex in four replicate plants. Chlorophyll content of these leaves was also measured 9 days after treatment with a Fuji Greenmeter (Fuji Co.).

Experiment 2. Effect of high root temperature on the photosynthate translocation and metabolism in the root

The plant preparation was the same as described in Experiment 1, except that this experiment was conducted in a growth chamber main tained at $25^{\circ} / 20^{\circ} \mathrm{C}$ (air, day/ night) and a $13-\mathrm{h}$ photoperiod of $300 \mu \mathrm{mol} \mathrm{s}{ }^{-1} \mathrm{~m}^{-2}$ PAR at canopy level. The nutrient solution was kept at $25^{\circ}$ or $38^{\circ} \mathrm{C}$. About $50 \mathrm{~min}$ before the end of the photoperiod on the 6 th day of temperature treatment, plants were placed in an acrylic chamber as illus. trated in Fig. 1. The shoot chamber measured 44 $\times 27 \times 30 \mathrm{~cm}(\mathrm{~L} \times \mathrm{W} \times \mathrm{H})$, with a 1 -liter plastic bottle attached to its bottom as a root chamber. This root chamber containing $800 \mathrm{~m} l$ of halfstrength Hoagland solution was in turn immersed in a water bath maintained at $25^{\circ}$ or $38^{\circ} \mathrm{C}$.

The shoot was pulse-fed with $2 \mu \mathrm{Ci}{ }^{14} \mathrm{CO}_{2}$ by adding $20 \%$ lactic acid to a $\mathrm{Na}^{14} \mathrm{CO}_{3}$ solution. In order to raise the initial $\mathrm{CO}_{2}$ concentration in the shoot chamber to $500 \mathrm{ppm}$, an appropriate amount of non-labeled $\mathrm{NaCO}_{3}$ was added to the $\mathrm{Na}^{14} \mathrm{CO}_{3}$ solution. Air in the shoot chamber was agitated continuously using a small fan. After a 30 -min feeding, fresh air was passed through the shoot

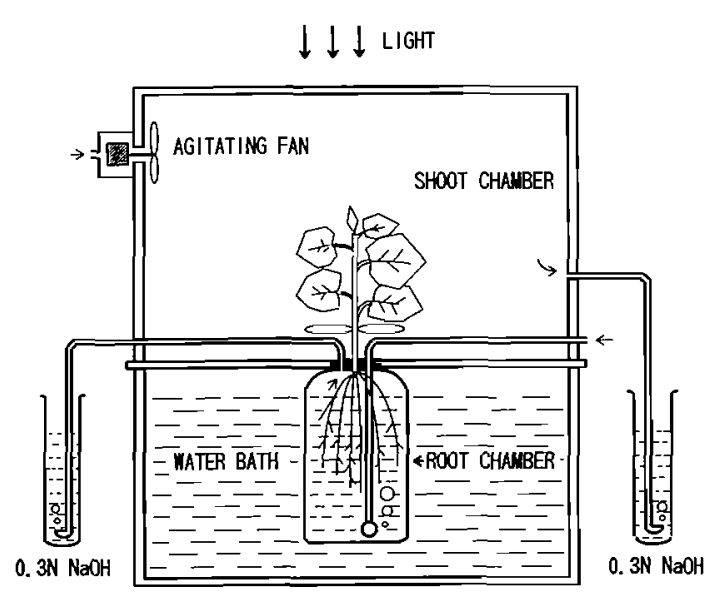

Fig. 1. Diagramatic presentation of the assimilation chamber used in pulse-feeding ${ }^{14} \mathrm{CO}_{2}$ and collecting the respired $\mathrm{CO}_{2}$ (Experiment 2). For details see text. 
chamber and bubbled through $\mathrm{NaOH}$ solution for 10 min to remove unfixed ${ }^{14} \mathrm{CO}_{2}$. Then, the shoot chamber was opened temporarily to remove completely the unfixed ${ }^{14} \mathrm{CO}_{2}$, and then resealed. During the following a 10-h chase period in the dark, fresh air was continuously pumped through the shoot $\left(400 \mathrm{ml} \cdot \mathrm{min}^{-1}\right)$ and the root $(350 \mathrm{~m} l$. $\min ^{-1}$ ) chambers separately, and the exiting air was bubbled through $0.3 \mathrm{~N} \mathrm{NaOH}$ solution to trap the ${ }^{14} \mathrm{CO}_{2}$ respired by the shoot or the roots.

${ }^{14} \mathrm{CO}_{2}$-fed plants were harvested and separated into leaves, stem (including petioles), and roots. Samples were freeze-dried, ground and prepared with Aloka Automatic Combusion System for liquid scintilation counts. The ${ }^{14} \mathrm{C}$ accumulated in the root tissue was fractionated to ethanol-soluble and ethanol-insoluble compounds by extracting the root samples with a mixture of $95 \%$ ethanol-waterformic acid (33:7:2 by volume; Cataldo and Berlyn, 1974). The ethanol-soluble fraction was separated into sugars, amino acids, organic acids, and sugar phosphates following the procedures of Cataldo and Berlyn (1974). The sugar fraction was further separated to hexoses, sucrose, raffinose and stachyose by HPLC on a Fine-Pak-Sil$\mathrm{NH}_{2}$ column. The column was eluted with $70 \%$ acetonitrile at $1 \mathrm{ml} \cdot \mathrm{min}^{-1}$, and the eluates corresponding to the sugar peaks were collected and dried under $\mathrm{N}_{2}$ gas. Radioactivity of these fractions, the ${ }^{14} \mathrm{CO}_{2}$ traps, the nutrient solution and the preparations of various plant parts was counted in a liquid scintilation counting system (Beckman LS-1801). Relative sink activity (RSA) of the root was calculated according to the following equation (Dinar and Rudich, 1985):

$$
\begin{aligned}
& \mathrm{RSA}= \\
& \frac{\mathrm{dpm} \cdot \mathrm{g}^{-1} \mathrm{~d} . \mathrm{wt} \text { in the root (including respired }{ }^{14} \mathrm{C} \text { ) }}{\mathrm{dpm} \cdot \mathrm{g}^{-1} \text { d.wt in the whole plant (including respired }{ }^{14} \mathrm{C} \text { ) }}
\end{aligned}
$$

\section{Results}

\section{Experiment 1. Effect of high root temperature on the} leaf photosynthesis and transpiration

Leaf photosynthesis and transpiration showed no statistical difference among plants with roots kept at 25,32 and $35^{\circ} \mathrm{C}$ until 9 days after treatment (Table 1). With roots kept at $38^{\circ} \mathrm{C}$, the photosynthesis and transpiration rates were very similar to plants with roots at $25^{\circ} \mathrm{C}$ after a 5 day treatment. The rates decreased sharply, particularly in the upper leaves, when measured after 9 days. Leaf chlorophyll content of the plants grown at $38^{\circ} \mathrm{C}$ was also much lower than that at the lower temperatures. Such a decrease of chlorophyll content was more pronounced in young leaves.

Experiment 2. Effect of high root temperature on the photosynthate translocation and meta. bolism in the root

Table 2 shows the concentration of ${ }^{14} \mathrm{C}$-photosynthates accumulated in plant parts as well as the amount of ${ }^{14} \mathrm{C}$ respired by a unit dry weight of the shoot or the roots. The total amount of ${ }^{14} \mathrm{C} \mathrm{im}$ ported on a unit dry weight of root was significantly higher in roots kept at $38^{\circ} \mathrm{C}$ then at $25^{\circ} \mathrm{C}$, the respiratory loss of ${ }^{14} \mathrm{CO}_{2}$ from roots was also greater at $38^{\circ} \mathrm{C}$ than at $25^{\circ} \mathrm{C}$, consequently, the ${ }^{14} \mathrm{C}$ concentration in the root did not differ significantly between those kept at $25^{\circ}$ or $38^{\circ} \mathrm{C}$. Plants at $38^{\circ} \mathrm{C}$ had less ${ }^{14} \mathrm{C}$ in the stem, compared to those at $25^{\circ} \mathrm{C}$, which may indicate a faster movement of ${ }^{14} \mathrm{C}$-photosynthates towards the root.

Table 3 shows the ${ }^{14} \mathrm{C}$-photosynthates accumulated and respired in various plant parts as ex. pressed in percent of total ${ }^{14} \mathrm{C}$ fixed by the plant. The percentage of total ${ }^{14} \mathrm{C}$ translocated to the root was $11.9 \%$ in the $38^{\circ} \mathrm{C}$ treatment, significantly higher than the $8.6 \%$ in the $25^{\circ} \mathrm{C}$ treatment. Of the ${ }^{14} \mathrm{C}$-photosynthates imported by the root, $41 \%$ was lost through respiration and $59 \%$ remained in the root tissues at $38^{\circ} \mathrm{C}$. This is in sharp contrast to the $22 \%$ and $78 \%$, respectively at $25^{\circ} \mathrm{C}$.

Our data also show that the roots grown at $38^{\circ} \mathrm{C}$ had a higher relative sink activity (RSA) than did those kept at $25^{\circ} \mathrm{C}$. RSA value compares the activity of an organ as a sink for photosynthates disregarding the difference in plant size. The results of this experiment seem to indicate that in cucumber, high root temperature promotes the translocation of currently fixed carbon to the root. However, because of increased carbon loss by respiration, the accelerated translocation does not contribute to the carbon available for root growth. The amount of ${ }^{14} \mathrm{C}$ lost from the root to the nutrient solution was insignificant; therefore, it was not included in the computation.

Root temperature caused changes in the metabolism of ${ }^{14} \mathrm{C}$-photosynthates translocated to the root as more ${ }^{14} \mathrm{C}$ was found in the soluble fraction and 
Table 1. Effects of root temperatures on the photosynthetic and transpiration rates and chlorophyll content of cucumber leaves. Values are the means $\pm \mathrm{SE}$ of 4 or 6 replicates (Experiment 1 ).

\begin{tabular}{|c|c|c|c|c|c|c|}
\hline \multirow{2}{*}{$\begin{array}{l}\text { Root temp. } \\
\quad\left({ }^{\circ} \mathrm{C}\right)\end{array}$} & \multirow{2}{*}{$\begin{array}{l}\text { Leaf } \\
\text { number }\end{array}$} & \multicolumn{2}{|c|}{$\begin{array}{c}\text { Photosynthesis } \\
\left(\mathrm{mg} \mathrm{CO}{ }_{2} \cdot \mathrm{dm}^{-2} \cdot \mathrm{h}^{-1}\right)\end{array}$} & \multicolumn{2}{|c|}{$\begin{array}{c}\text { Transpiration } \\
\left(\mathrm{g} \mathrm{H}_{2} \mathrm{O} \cdot \mathrm{dm}^{-2} \cdot \mathrm{h}^{-1}\right)\end{array}$} & \multirow{2}{*}{$\frac{\begin{array}{c}\text { Chlorophyll } \\
\left(\mathrm{mg} \cdot \mathrm{dm}^{-2}\right)\end{array}}{9 \text { days }}$} \\
\hline & & 5 days $^{y}$ & 9 days & 5 days & 9 days & \\
\hline \multirow[t]{4}{*}{25} & 1 & $15.7 \pm 1.3$ & $15.7 \pm 0.7$ & $6.4 \pm 0.4$ & $5.3 \pm 0.2$ & $3.45 \pm 0.34$ \\
\hline & 2 & $19.6 \pm 1.9$ & $16.8 \pm 1.2$ & $6.3 \pm 1.8$ & $5.7 \pm 0.2$ & $3.90 \pm 0.28$ \\
\hline & 3 & $20.2 \pm 1.5$ & $18.0 \pm 1.7$ & $6.7 \pm 1.3$ & $5.6 \pm 0.5$ & $4.12 \pm 0.37$ \\
\hline & 4 & & $19.2 \pm 1.6$ & & $5.9 \pm 0.3$ & $4.57 \pm 0.24$ \\
\hline \multirow[t]{4}{*}{32} & 1 & $18.2 \pm 1.7$ & $16.1 \pm 1.7$ & $6.5 \pm 1.2$ & $5.6 \pm 0.4$ & $4.57 \pm 0.22$ \\
\hline & 2 & $20.7 \pm 1.0$ & $18.8 \pm 1.3$ & $6.9 \pm 1.1$ & $6.0 \pm 0.4$ & $4.21 \pm 0.22$ \\
\hline & 3 & $20.8 \pm 1.8$ & $20.9 \pm 1.9$ & $6.9 \pm 1.4$ & $6.1 \pm 0.4$ & $4.58 \pm 0.34$ \\
\hline & 4 & & $20.0 \pm 1.7$ & & $6.2 \pm 0.3$ & $5.13 \pm 0.36$ \\
\hline \multirow[t]{4}{*}{35} & 1 & $18.0 \pm 1.3$ & $16.2 \pm 1.2$ & $6.9 \pm 1.5$ & $5.6 \pm 0.5$ & $4.11 \pm 0.36$ \\
\hline & 2 & $20.0 \pm 1.3$ & $19.1 \pm 1.1$ & $7.1 \pm 1.7$ & $5.7 \pm 0.8$ & $4.69 \pm 0.37$ \\
\hline & 3 & $21.5 \pm 1.9$ & $20.0 \pm 1.9$ & $7.4 \pm 1.5$ & $5.9 \pm 0.2$ & $4.85 \pm 0.35$ \\
\hline & 4 & & $21.5 \pm 1.0$ & & $6.3 \pm 0.5$ & $5.43 \pm 0.26$ \\
\hline \multirow[t]{4}{*}{38} & 1 & $15.7 \pm 1.0$ & $4.2 \pm 1.0$ & $6.7 \pm 1.9$ & $2.4 \pm 0.3$ & $1.53 \pm 0.16$ \\
\hline & 2 & $18.6 \pm 1.5$ & $6.0 \pm 1.0$ & $6.4 \pm 1.7$ & $2.7 \pm 0.2$ & $2.70 \pm 0.25$ \\
\hline & 3 & $20.4 \pm 1.7$ & $8.6 \pm 1.7$ & $6.7 \pm 1.9$ & $3.0 \pm 0.6$ & $3.11 \pm 0.17$ \\
\hline & 4 & & $10.7 \pm 1.7$ & & $3.4 \pm 0.7$ & $3.12 \pm 0.37$ \\
\hline
\end{tabular}

$\approx$ Leaves were numbered basipetally starting with the third leaf from the stem apex.

$y$ Days of temperature treatments.

Table 2. The concentrations of ${ }^{14} \mathrm{C}$-photosynthates accumulated in the various organs of cucumber plants as influenced by root temperatures. After 6 days growing at the given root temperatures the shoot of cucumber seedlings was pulse-fed with ${ }^{14} \mathrm{CO}_{2}$ for $30 \mathrm{~min}$, followed by a 10 -h chase in the dark (Experiment 2).

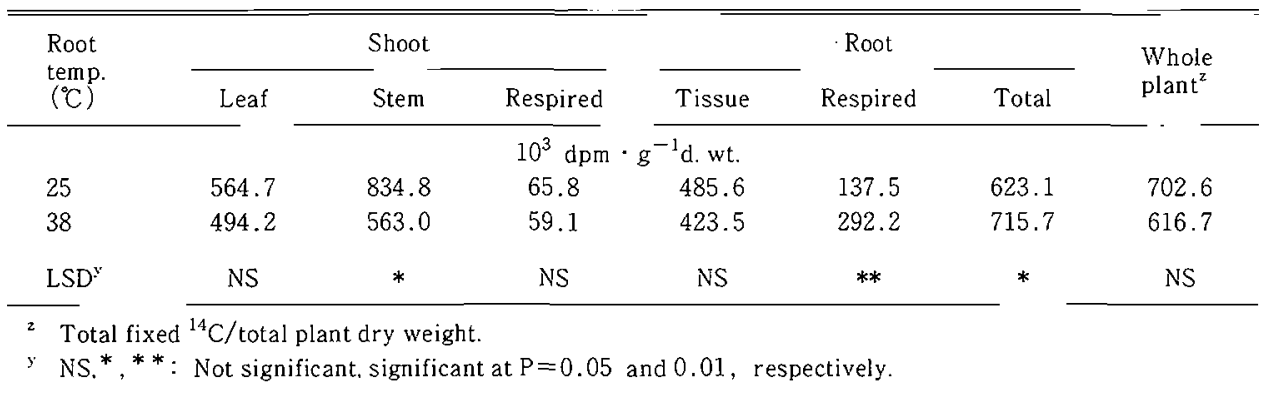

Table 3. Percentages of ${ }^{14} \mathrm{C}$-photosynthates partitioned to the various organs of cucumber plants as influenced by root temperatures. After 6 days growing at the given root temperatures the shoot of cucumber seedlings was pulse-fed with ${ }^{14} \mathrm{CO}_{2}$ for $30 \mathrm{~min}$, followed by a 10 -h chase in the dark (Experiment 2) .

\begin{tabular}{|c|c|c|c|c|c|c|c|}
\hline \multirow{2}{*}{$\begin{array}{l}\text { Root } \\
\text { temp. } \\
\left({ }^{\circ} \mathrm{C}\right)\end{array}$} & \multicolumn{3}{|c|}{ Shoot } & \multicolumn{3}{|c|}{ Root } & \multirow{2}{*}{$\begin{array}{l}\text { Root } \\
\operatorname{RSA}^{z}\end{array}$} \\
\hline & Leaf & Stem & Respired & Tissue & Respired & Total & \\
\hline 25 & 46.0 & 35.4 & 10.0 & $6.7(78)^{y}$ & $1.9(22)$ & $8.6(100)$ & 0.89 \\
\hline 38 & 42.8 & 32.8 & 12.5 & $7.0(59)$ & $4.9(41)$ & $11.9(100)$ & 1.16 \\
\hline $\operatorname{LSD}^{x}$ & NS & NS & NS & NS & $*$ & * & $*$ \\
\hline
\end{tabular}

$\therefore$ Relative Specific Activity. See Materials and Methods.

$y$ Data in parentheses are the percent of the total ${ }^{14} \mathrm{C}$ partitioned to the root.

${ }^{*} \mathrm{NS}^{*},{ }^{*}$ : Not significant, significant at $\mathrm{P}=0.05$ and 0.01 , respectively. 
less in the insoluble fraction in the roots at $38^{\circ}$ than at $25^{\circ} \mathrm{C}$ (Fig. 2). Of the ${ }^{14} \mathrm{C}$ translocated into the roots, $64.6 \%$ and $45.4 \%$ were incorporated into the insoluble compounds in the roots grown at 25 and $38^{\circ} \mathrm{C}$, respectively (Fig. $2 \mathrm{~B}$ ).

In the $38^{\circ} \mathrm{C}$ treatment, the sugar fraction was markedly more radioactive than the amino and organic acid fractions, whereas in the $25^{\circ} \mathrm{C}$ treatment, the radioactivities of the three fractions were approximately identical (Fig. 3). Thus, the percent distribution of ${ }^{14} \mathrm{C}$-sugars in the total soluble ${ }^{14} \mathrm{C}$ was very high and that of the organic acid fraction was extremely low in roots at $38^{\circ} \mathrm{C}$ compared with those roots at $25^{\circ} \mathrm{C}$ (Fig. $3 \mathrm{~B}$ ).
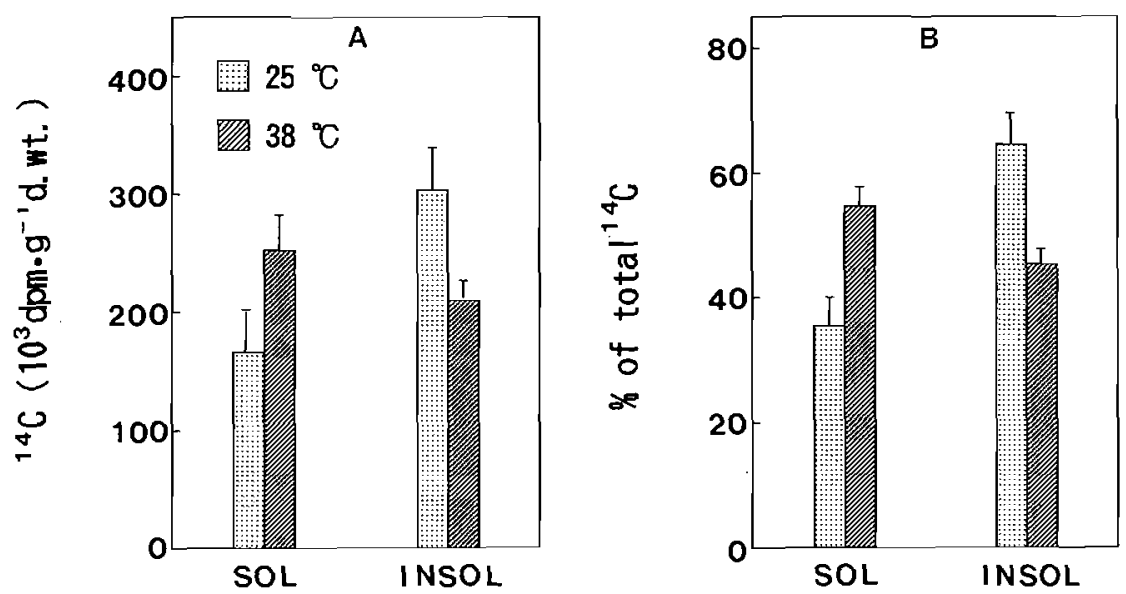

Fig. 2. Effect of root temperatures on the partitioning of ${ }^{14} \mathrm{C}$-photosynthates to the ethanol soluble (SOL) and insoluble (INSOL) fractions in the root tissue of cucmber plant (Experiment 2). After 6 days growing at the given root temperatures the shoot was pulsefed with ${ }^{14} \mathrm{CO}_{2}$ for $30 \mathrm{~min}$, followed by a 10 -h chase in the dark. Values are presented as (A) radioactivity on the dry weight basis and (B) percent of the total radioactivity. Vertical lines represent SE.
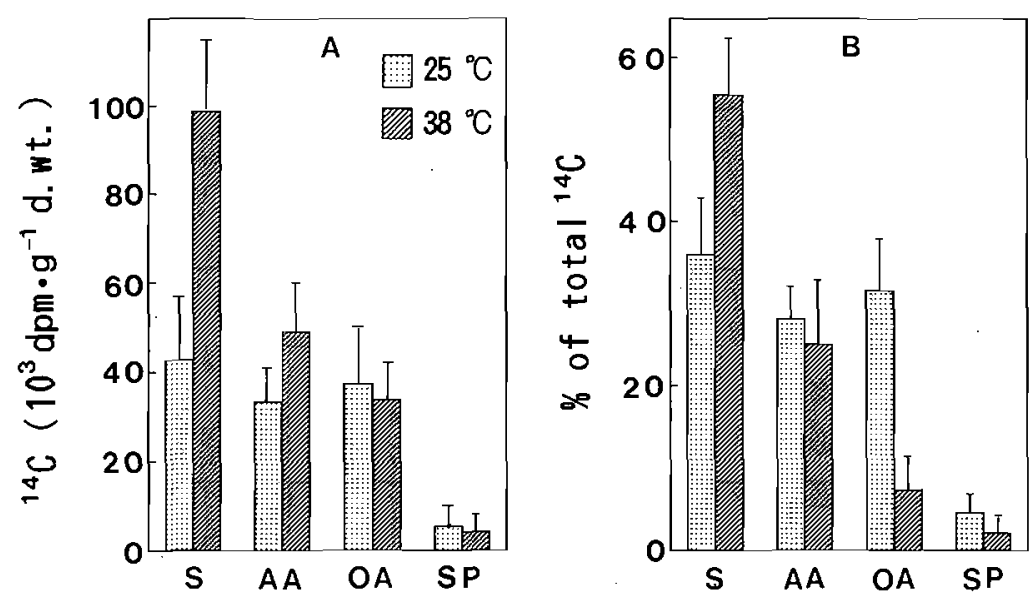

Fig. 3. Effect of root temperatures on the incorporation of ${ }^{14} \mathrm{C}$-photosynthates into sugars (S), amino acids (AA), organic acid (OA) and sugar phosphates (SP) in the roots of cucumber plant (Experiment 2). After 6 days growing at the given root temperatures the shoot was pulse-fed with ${ }^{14} \mathrm{CO}_{2}$ for 30 min, followed by a 10 -h chase in the dark. Values are presented as (A) radioactivity on the dry weight basis and (B) percent of the total radioactivity. Vertical lines represent SE. 
The determination of individual sugars revealed that reffinose, sucrose and hexoses in the roots grown at $38^{\circ} \mathrm{C}$ were significantly more radioactive than those in the roots kept at $25^{\circ} \mathrm{C}$ (Fig. 4). The percent distribution of ${ }^{14} \mathrm{C}$-raffinose increased, while ${ }^{14} \mathrm{C}$-stachyose decreased at the high root temperature, but those of ${ }^{14} \mathrm{C}$-hexoses and -sucrose were unaffected (Fig. 4B).

\section{Discussion}

The results of the present study showed that the effect of high root temperatures on photosynthesis of cucumber leaves appeared later than they did on the root growth. After 5 days of root exposure to $38^{\circ} \mathrm{C}$, the photosynthetic rate did not differ from that exposed to $25^{\circ} \mathrm{C}$, whereas the root growth was much inhibited (data not presented). It seems reasonable to assume that the root growth inhibition by high root temperature is not primarily related to the leaf photosynthesis. However, when small plants were exposed to such high root temperature for 9 days, a decrease in photosynthesis occurred, which limited root growth

The decrease of photosynthesis in cucumber leaves after 9 days growth in the $38^{\circ} \mathrm{C}$ treatment may be partly ascribed to the decrease in leaf chlorophyll content, as reported by Ruter and Ing- ram (1992). In addition, stomatal closure as indicated by the decrease of leaf transpiration rate may also play a role in the decline of photosyn. thesis. There is evidence that the decrease in photosynthetic capacity and chlorophyll content in response to high root temperature is related to the reduction of cytokinin production by the root (Itai et al., 1973; Caers et al., 1985). The deficiency of mineral nutrients in leaves may be an additional determination factor. Heat treatment of roots significantly reduces the concentration of mineral nutrients in the root exudate (BassiriRad and Radin, 1992). The photosynthesis of plants grown in $35^{\circ} \mathrm{C}$ treatment showed no decrease during 9 days period, but this root temperature greatly re. duced the leaf mineral content; especially with the prolongation of the treatment (Du and Tachibana, 1994). Thus, the photosynthesis of the plants grown at $35^{\circ} \mathrm{C}$ would be gradually reduced if the treatment is extended.

The translocation of photosynthates to the root was significantly promoted at $38^{\circ} \mathrm{C}$, which is contrary to the result of Sattelmacher et al. (1990b). They found that elevating temperature of potato roots from 20 to $30^{\circ} \mathrm{C}$ greatly decreased ${ }^{14} \mathrm{C}$ photosynthate translocation to the roots. In their experiment high temperature did not stimulate, but
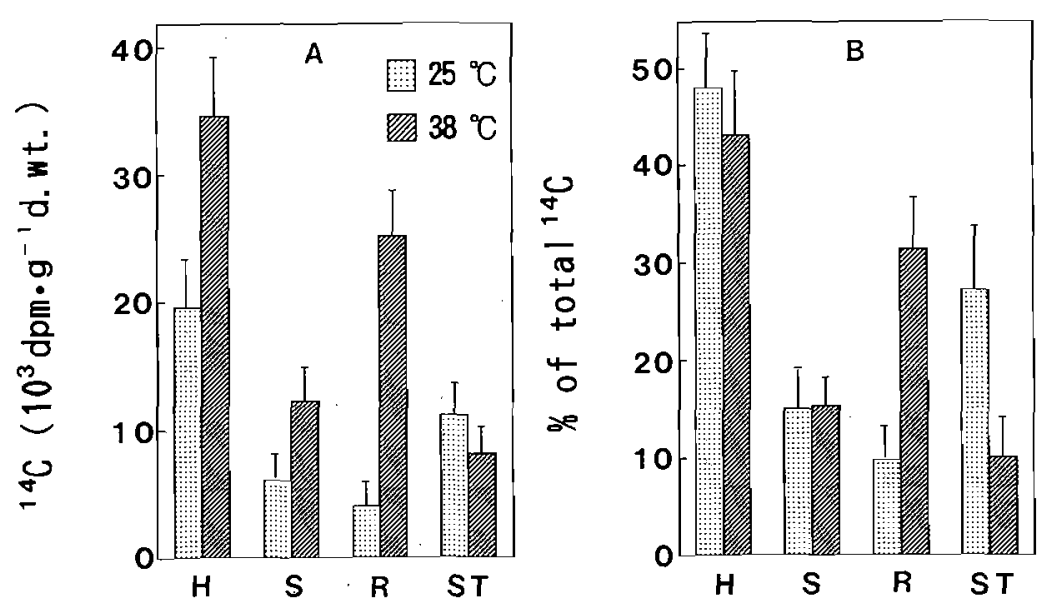

Fig. 4. Effect of root temperatures on the incorporation of ${ }^{14} \mathrm{C}$-photosynthates into hexoses $(H)$, sucrose $(S)$, raffinose $(R)$ and stachyose $(S T)$ in the root tissue of cucumber plant (Experiment 2). After 6 days growing at the given root tempera. tures the shoot was pulse-fed with ${ }^{14} \mathrm{CO}_{2}$ for $30 \mathrm{~min}$, followed by a 10 -h chase in the dark. Values are presented as (A) radioactivity on the dry weight basis and $(B)$ percent of the total radioactivity. Vertical lines represent SE. 
inhibited in some cases, root respiration. This observation is quite contrary to ours in that exposure of cucumber roots to high temperatures caused a marked increase in the root respiration (Du and Tachibana, 1994). Since respiration is an important component of root sink activity (Lambers, 1987), the differential respiratory response of roots to high temperatures may partly account for the above discrepancy between cucumber and potato with respect to photosynthate translocation.

According to Shishido et al. (1987), in cucumber the rate of carbon export from a source leaf is greater during the day than during the night. Our results do not provide any answer as to the difference in the rates of translocation of photosynthates during the day or night. In any case, the increased rate of photosynthate translocation to the root could hardly contribute to the availability of carbon assimilates to the root growth because the high temperature increased carbon loss through root respiration. Furthermore, since the increase in root respiration by high temperatures in cucum. ber is manifested as a result of stimulation of the alternative electron transport pathway $(\mathrm{Du}$ and Tachibana, 1994), most of the increased photosynthates translocated to the root would be wasted in view of energy production.

High temperature reduced the incorporation of ${ }^{14} \mathrm{C}$-photosynthates into insoluble compounds while increasing their accumulation in soluble compounds in the roots. Similar observations have been made in the roots of other plants or in fruits (Dinar and Rudish, 1985; Ruter and Ingram, 1990; Sattlemacher et al., 1990b). These results indicate an inhibitory effect of high temperature on some carbon utilization processes other than respiration. The inhibitory effect has been reported on the synthesis of starch (Sattlemacher et al., 1990a), protein (Aloni et al., 1992) and cell wall components (Du and Tachibana, 1994). As previously observed, a large amount of ${ }^{14} \mathrm{C}$-raffinose accumulated in roots grown at $38^{\circ} \mathrm{C}$. Probably, the enzymatic processes of raffinose hydrolysis was impeded by the high temperature.

In conclusion, heat stress on the rool of cucumber plants initially promoted the translocation of photosynthates into the root to meet the increased demand of carbohydrates for respiratory substrates. However, because of the disturbance of normal carbon metabolisms, root growth and func- tions such as uptake and transport of water and nutrients, and plant hormone production may deteriorate. This may cause the gradual decline of photosynthesis; the consequent decrease of carbon supply to the roots further limits root growth and functions.

\section{Literature Cited}

Aloni, B., L. Karni and J. Daie. 1992. Effect of heat stress on the growth, root sugars, acid invertase and protein profile of pepper seedlings following transplanting. J. Hort. Sci. $67: 717-725$.

BassiriRad, H. and J. W. Radin. 1992. Temperature-dependent water and ion transport properties of barley and sorghum roots. II. Effect of abscisic acid. Plant Physiol. 99: 34-37.

Caers, M., P. Rudelsheim, H. V. Onckelen and S. Horemans. 1985. Effect of heat stress on photosynthetic activity and chloroplast ultrastructure in correlation with endogenous cytokinin concentration in maize seedlings. Plant Cell Physiol. 26 : 47-52.

Cataldo, D. A. and G. P. Berlyn. 1974. An evaluation of selected physical characteristics and metabolism of enzymatically separated mesophyll cells and minor veins of tobacco. Amer. J. Bot. 61 : 957-963.

Chaisompongpan, N., P. H. Li, D. W. Davis and A. H. Markhart. 1989. Root cooling protects plants from heat injury. Plant Physiol. 89 (supplement): 32.

Dinar, M. and J. Rudich. 1985. Effect of heat stress on assimilate metabolism in tomato flower buds. Ann. Bot. $56: 249-257$.

Du, Y. C. and S. Tachibana. 1994. Effect of supraoptimal root temperature on the growth, root respiration and sugar content of cucumber plants. Scientia Hortic. (in press)

Gross, K. C. and D. M. Pharr. 1982. A potential pathway for galactose metabolism in Cucumis sativus L., a stachyose transporting species. Plant Physiol. $69: 117-121$.

Gur, A., B. Bravdo and Y. Mizrahi. 1972. Physiological responses of apple trees to supraoptimal root temperature. Physiol. Plant. 27 : 130-138.

Hurewitz, J. and H. W. Janes. 1983. Effect of altering the rootzone temperature on growth, translocation, carbon exchange rate, and leaf starch accumulation in the tomato. Plant Physiol. 73:46-50.

Itai, C., A. Ben-Zioni and L. Ordin. 1973. Correlative changes in endogenous hormone levels and shoot growth induced by short heat treatments to the root. Physiol. Plant. $29:$ 355-360.

Janes, H. W., C-K. Chin and J. Bachmansky. 1988. Growth and metabolism of tomato roots grown in tissue cultures held at various temperatures. HortScience $23: 773$. 
Kuroyanagi, T. and G. M. Paulsen. 1988. Mediation of high-temperature injury by roots and shoot during reproductive growth of wheat. Plant Cell Environ. $11: 517-523$.

Lambers, H. 1987. Growth, respiration, exudation and symbiotic associations: The fate of carbon translocated to the roots. p. 125-145. In: P. J. Gregory, J. V. Larke and D. A. Rose (eds.). Root development and function. Cambridge University Press, UK.

Murata, T., S. Morita and Y. Ohmori. 1975. Falling nutrient solution temperature in summer water culture: Actual conditions and effect of shading materials. Bull. Osaka Agr. Res. Cent. 12:59-70. (In Japanese with English summary).

Reynolds, M. P. and E. E. Ewing. 1989. Effect of high air and soil temperature stress on growth and tuberization in Solanum tuberosum. Ann. Bot. 64: 241-247.

Rudich, J., E. Zamski and Y. Regey. 1977. Genotypic variation for sensitivity to high temperature in the tomato: pollination and fruit set. Bot. Gaz. 138 : $448-452$

Ruter, J. M. and D. L. Ingram. 1990. ${ }^{14}$ Carbon-labeled photosynthate partitioning in llex crenata 'Rotundifolia' at supraoptimal root-zone temperatures. J. Amer. Soc. Hort. Sci. $115: 1008-1013$.
Ruter, J. M. and D. L. Ingram. 1992. High root-zone temperatures influence RuBisCO activity and pigment accumulation in leaves of 'Rotundifolia' hol1y. J. Amer. Soc. Hort. Sci. $117:$ : 154-157.

Sasaki, K. and T. Itagi. 1989. Effect of root cooling treatment of nutrient solution on growth and yield of tomato, cucumber and melon. Environ. Control in Biol. $27: 89-95$ (In Japanese with English summary).

Sattelmacher, B., H. Marschner and R. Kühne. 1990a. Effects of the temperature of the rooting zone on the growth and development of roots of potato (Solanum tuberosum). Ann. Bot. $65: 27-36$.

Sattelmacher, B., H. Marschner and R. Kühne. 1990b. Effects of root zone temperature on root activity of two potato (Solanum tuberosum L.) clones with different adaptation to high temperature. J. Agro. Crop Sci. $165: 131-137$.

Shishido, Y., H. Challa and J. Krupa. 1987. Effects of temperature and light on the carbon budget of young cucumber plants studied by steady-state feeding with ${ }^{14} \mathrm{CO}_{2}$. J. Exp. Bot. 38:1044-1054.

Sugiyama, T., S. Iwahori and T. Takahashi. 1966. Effect of high temperature on fruit setting of tomato under cover. Acta Hortic. 4 : 63-69.

キュウリの光合成，根への光合成産物の転流とその代謝に及ぼす高根温の影響

杜 永臣・樀 昌司

三重大学生物資源学部 514 津市上浜町

摘 要

$25^{\circ} \mathrm{C}$ から $38^{\circ} \mathrm{C} の$ 根温で生育したキュウリ幼植物の 光合成速度拉よび $25^{\circ} \mathrm{C}$ と $38^{\circ} \mathrm{C}$ の根温で生育したキ エウリの根への光合成產物の転流とその代謝を調べた。

光合成速度は，根温 $25^{\circ} \mathrm{C}, 32{ }^{\circ} \mathrm{C}$ と $35^{\circ} \mathrm{C}$ の間に大

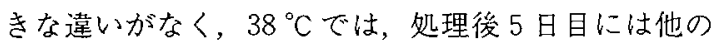
処理区とあまり違わなかったが，9日目になると非常 に低下した。また， $38^{\circ} \mathrm{C}$ 区の菜の蒸散速度とクロロ フィル含有量も, 光合成速度と同じように 9 日目に著

しく低下した。

一方, 光合成産物の根への転流率は $25^{\circ} \mathrm{C}$ 区より 38 ${ }^{\circ} \mathrm{C}$ 区のほうが高く, $38^{\circ} \mathrm{C} て ゙$ 生育している根は相対シン ク強度が高かった。しかし, $38^{\circ} \mathrm{C}$ 区の根は呼吸による
光合成產物の損失忙が $25^{\circ} \mathrm{C}$ 区より多く、このため而 区の根の光合成産物の蓄皘量には大きな差がなかった。

高根温は, 根組織に蓄積した ${ }^{14} \mathrm{C}$-光合成産物の工 タノール不溶性分画への分配を阻害し, 可溶性分画へ の分配を增加することが認められた，可溶性分画にお いては, $25^{\circ} \mathrm{C} て ゙ は{ }^{14} \mathrm{C}$-光合成産物は可溶性糖, 有機 酸アアミノ酸にほほ均等に分配されたのに対して，38 ${ }^{\circ} \mathrm{C}$ では可溶性糖, 特にラフィノース. ${ }^{14} \mathrm{C}$ 量が著し く高かった。

以上の結果より，高根温によるキュウリ根の生長抑 制と機能の低下には，根に扔ける光合成産物の代謝の 異常が密接に関与していると考えられる. 